\title{
ANALISIS JUMLAH KROMOSOM PADA TRIPLOIDISASI IKAN MAS (Cyprinus carpio Linn) RAS PUNTEN DENGAN LAMA PERENDAMAN KEJUT SUHU PANAS YANG BERBEDA
}

\author{
Rahmad Hendro Susilo', Farikhah ${ }^{2}$, dan Andi Rahmad Rahim² \\ 1) Mahasiswa Prodi Budidaya Perikanan, Fakultas Pertanian Universitas Muhammadiyah Gresik \\ 2) Dosen Prodi Budidaya Perikanan Fakultas Pertanian Universitas Muhammadiyah Gresik \\ Email : hendro_susi@yahoo.com, Phone +6281555427055
}

\begin{abstract}
Goldfish (Cyprinus carpio Linn) punten breeds is a type of freshwater fish that has great potential in terms of quality and quantity. Seed production from generation to generation has decreased quality. An alternative effort was made to maintain the seed quality of genetic engineering with triploidization process using heat shock treatment. The heat shock can prevent polar body II from splitting on eggs during cleavage of meiosis II level resulting in $3 \mathrm{~N}$ chromosome or sterile fish. The purpose of this research is to analyze chromosome number in triploidization process of punten breeds fish and to analyze the effect of temperature shock duration on hatching rate of goldfish (Cyprinus carpio Linn) Punten Breeds. This research was descriptive research with 2 treatments and 3 replications in each treatment that was heat shock treatment $40{ }^{\circ} \mathrm{C}$ at minute 2 after fertilization with difference of heat shock duration 1,5 minutes (treatment A) and shock time temperature 2 minutes (treatment B). The parameters observed were triploid success, hatching rate, survival rate, and growth of of goldfish (Cyprinus carpio Linn) Punten Breeds, analyzed by T-test with $95 \%$ confidence interval. The result of heat shock duration of 1.5 minutes showed the percentage of triploid fish 53,57\% and shock time temperature 2 minute $43,64 \%$. The result of T-test of both treatments had no significant effect on all observation parameters but had varied relationship that was enough and inversely related to all observation parameters.
\end{abstract}

Keywords: Goldfish Punten Breeds, Triploidization, Temperature shock time, and $3 N$ chromosome.

\section{PENDAHULUAN}

Ikan mas (Cyprinus carpio Linn) merupakan jenis ikan air tawar yang memiliki pontensi besar untuk dikembangkan dan dipacu kualitas maupun pertumbuhan produksinya, guna pemenuhan gizi masyrakat. Salah satunya ikan mas ras Punten yang mempunyai keunggulan tertentu, yaitu pertumbuhan yang cepat dengan kualitas daging yang baik dan tebal (Mustami, 2013). Ikan mas Punten pertama kali dikembangkan pada tahun 1933 di Desa Punten, Kota Batu, Jawa Timur (Kumbarani, 2015). Kendala budidaya ikan mas ras punten yaitu penurunan kualitas benih yang dihasilkan dari waktu ke waktu sehingga belum mampu untuk memenuhi permintaan-permintaan tersebut (Firmantin dkk., 2015).

Rekayasa genetika dengan Triploidisaasi untuk membuat ikan kromosom 3N (triploid) yang mampu menunjang pertumbuhan menjadi lebih cepat dibandingkan dengan ikan normal yang mempunyai kromosom 2N (diploid) (Purnawan, 2016). Triploidisasi dilakukan dengan memberi kejutan panas pada telur yang dibuahi secara normal pada saat tingkat meiosis II. Pemberian kejutan tersebut diharapkan dapat mencegah terlepasnya polar-body II sehingga terbentuk keadaan triploid (Hariani, 2008). Keberhasilan triploid dipengaruhi oleh suhu kejutan, lama kejutan dan waktu kejutan setelah fertilisasi (Risnandar, 2010). Piferrer dkk., (2007) 


\section{Jurnal Perikanan Pantura (JPP) Volume 1, Nomor 1, Maret 2018}

menyatakan bahwa, tidak semua ikan bisa dilakukan proses triploidisasi dengan teknik kejutan panas atau kejutan dingin, karena setiap ikan memiliki ukuran telur yang berbeda-beda sehingga keefektifan perlakuan kejutan belum tentu berhasil. Ikan mas lebih baik menggunakan teknik kejutan suhu dan kejutan tekanan dalam proses triploidisasinya karena ikan ini memiliki ukuran telur yang kecil.

Edriani dkk (2009) menyatakan bahwa, waktu yang paling optimal untuk dilakukan triploidisasi adalah 2 menit untuk pembuahan dan lama kejutan 1,5 menit. Penelitian lanjutan perlu dilakukan dengan perlakuan lama kejut suhu panas yang berbeda pada proses triploidisasi untuk menganalisis pengaruh dan hubungan terhadap keberhasilan ikan triploid dengan menganalisis jumlah kromosom, survival rate, hatching rate, dan pertumbuhan Ikan Mas ras Punten.

Tujuan dari penelitian ini adalah untukMenganalisis pengaruh lama kejut suhu panas pada proses triploidisasi terhadap keberhasilan kromosom 3N (triploid), hatching rate, pada ikan Mas (Cyprinus carpio Linn) ras Punten. Penelitian ini diharapkan mampu menjadi bahan informasi bagi masyarakat khususnya para pembudidaya ikan dan sebagai salah satu bahan pertimbangan untuk penelitian lanjutan mengenai pengaruh lama kejutan panas pada proses triploidisasi terhadap keberhasilan ikan triploid, hatching rate, survival rate dan pertumbuhan pada ikan mas ras Punten.

\section{TINJAUAN PUSTAKA}

Santoso (2008) menyatakan bahwa, ikan mas terbagi tiga bagian, yaitu kepala, badan, dan ekor. Ikan mas juga memiliki mulut kecil yang membelah bagian depan kepala, sepasang mata, sepasang lubang hidung terletak di bagian kepala, dan tutup insang terletak di bagian belakang kepala. Seluruh bagian tubuh ikan mas ditutupi dengan sisik yang besar, dan berjenis cycloid yaitu sisik halus yang berbentuk lingkaran. Ikan Mas memiliki lima buah sirip, yaitu sirip punggung yang terletak di bagian punggung (dorsal fin), sirip dada yang terletak di belakang tutup insang (pectoralfin), sirip perut yang terletak pada perut (pelvic fin), sirip dubur yang terletak di belakang dubur (anal fin) dan sirip ekor yang terletak di belakang tubuh dengan bentuk cagak (caudal fin) (Santoso, 2011). Morfologi ikan mas strain Punten sebagai berikut: (1) warna sisik hijau kehitaman dengan bagian perut berwarna putih, (2) mata agak menonjol, (3) gerakan lamban dan jinak, (4) badan relatif paling pendek dari ras strain yang lain dengan punggung tinggi. Susanto (2004), ikan mas (Cyprinus carpioLinn) mempunyai telur yang sifatnya merekat/menempel atau adhesif.

Poliploidisasi adalah proses atau kejadian yang menyebabkan individu berkromosom lebih dari dua set, salah satunya adalah triploidisasi. Triploidisasi adalah proses membentuk ikan berkromosom 3N (triploid) sehingga ikan bersifat steril. Individu tersebut memiliki laju pertumbuhan yang lebih tinggi dibanding dengan individu normal, karena individu triploid tidak membutuhkan energi untuk perkembangan gonadnya sehingga energi tersebut dapat digunakan untuk pertuinbuhan tubuhnya (Widiyanti, 2008). Pembentukan ikan triploid dilakukan dengan memberi kejutan panas pada telur yang dibuahi secara normal pada saat tingkat meiosis II. Pemberian kejutan tersebut diharapkan dapat mencegah terlepasnya polar-body II sehingga terbentuk keadaan triploid (Nurasni, 2012). Ikan triploid dapat dihasilkan dengan dua cara, yaitu melalui pembuatan ikan tetraploid disilangkan dengan ikan diploid atau melalui penghambatan peloncatan polar body II pada saat meiosis II. 
Jurnal Perikanan Pantura (JPP) Volume 1, Nomor 1, Maret 2018

\section{METODE PENELITIAN}

Penelitian ini dilaksanakan pada bulan September sampai dengan November 2017, selama 80 hari, 40 hari proses triploidisasi di ruang karantinaInstalasi Budidaya Air Tawar (IBAT) Punten Kota Batu dan 40 hari karyotipe di Laboratorium Sentral Ilmu-ilmu Hayati Universitas Brawijaya (LSIH-UB) Malang.

Penelitian ini adalah penelitian deskriptif, sebagai perlakuan adalah kejut suhu panas $40^{\circ} \mathrm{C}, 2$ menit setelah fertilisasi dengan perbedaan lama kejut suhu panas yang dibagi 2 kelompok yaitu,

A. Lama kejutan suhu panas 1,5 menit

B. Lama kejutan suhu panas 2 menit

\section{Proses Triploidisasi}

Indukan betina distripingsampai keluar telur kemudian diletakkan dimangkok plastik persegi panjang. Indukan jantan juga distriping sampai keluar sperma, kemudian sperma diambil dengan spuit $1 \mathrm{ml}$ kemudian diteteskan digelas ukur dan ditambahkan dengan larutan Sodium chloride 0,9\% sebanyak $9 \mathrm{ml}$ kemudian dihomogenkan hingga tercampur. Telur diambil dari mangkok plastik dengan memakai spatula kemudian dicampur dengan menambah $1 \mathrm{ml}$ suspensi sperma sambil diaduk dengan bulu ayam sampai tercampur merata dalam wadah mangkok plastik. Telur yang tercampur sperma ditebar pada saringan dalam bak fiber yang telah terisi air sterile water untuk dilakukan fertilisasi selama 2 menit. Cara penebaran dengan arah zig-zag dengan menggunakan bulu ayam. Dilakukan pemberian kejutan suhu panas pada menit ke-2 setelah fertilisasi dengan suhu $40^{\circ} \mathrm{C}$ selama 1,5 menit (perlakuan A), dan 2 menit (perlakuan B) dengan menggunakan water bath. Telur dalam saringan yang sudah dikejut suhu diletakkan dalam aquarium ukuran 100 x 50 x $50 \mathrm{~cm}$ untuk dilakukan proses penetasan telur.

Preparasi Alat, Bahan dan Pembuatan Reagen untuk Analisis JumlahKromosom Teknik Jaringan Padat

Preparasi alat dan bahan pertama kali dengan mencuci botol bensin dan beaker glass masing-masing 3 buah yang telah direndam thypon dan bayclin selama satu malam. Botol yang sudah dicuci dioven selama 2-3 jam sampai tidak ada air yang menempel. Mensterilkan alat-alat uji lab seperti gunting, pinset, dan gelas arloji dengan dibungkus menggunakan aluminium foil terlebih dahulu. Botol yang sudah dioven diisi aquades 2 liter untuk disterilkan. Memasukkan botol yang berisi aquades ke dalam autoclave selama 2 jam lebih 30 menit beserta beaker glass, gunting, dan pinset yang telah dibungkus aluminium foil agar suhu panas tetap terkontrol. Alat yang sudah di sterilisasi menggunakan autoclave dioven sampai kering kecuali botol yang terisi aquades.

Pembuatan reagen dengan membuat larutan kolkisin 0,007\% w/v dengan mengambil air sumur 1 liter, kemudian menimbang bubuk kolkisin 0,074 mg dengan timbangan analitik, kemudian melarutkannya kedalam 1liter air. Mengaduk keduanya dengan hot plate hingga larutan kolkisin larut semua. Larutan kolkisin 1 liter dibagi menjadi 4 sesuai jumlah perlakuan yang akan diuji, masing-masing $250 \mathrm{ml}$ menggunakan wadah beaker glass. Membuat larutan hipotonik 0,075 $\mathrm{M}$ (1 liter) dengan menimbang 5,6 g $\mathrm{KCl}$ menggunakan timbangan analitik, kemudian melarutkannya kedalam 1 liter akuades, dan diaduk menggunakan hot plate pula. Membuat larutan carnoy dengan mencampurkan asam asetat glacial dan methanol dengan perbandingan 1:3 yaitu asam asetat 12,5 $\mathrm{ml}$ dan methanol $37,5 \mathrm{ml}$ dengan cara menuangkannya kedalam gelas ukur sesuai kebutuhan, kemudian menuangkannya ke dalam falcon untuk dilabeli. Membuat larutan alkohol $70 \%$ dengan mencampurkan etanol absolute, dengan akuades dengan perbandingan 7:3 (1 liter larutan alkohol 70\% $=700 \mathrm{ml}$ etanol absolute $+300 \mathrm{ml}$ akuades). Membuat larutan giemsa 20\% dengan mencampurkan giemsa dan akuades dengan perbandingan 
2:8 (100 ml larutan giemsa 20\% $=20 \mathrm{ml}$ giemsa $+80 \mathrm{ml}$ akuades $)$ dengan cara menuangkannya kedalam falcon kemudian diberi label. Langkah terakhir membuat larutan asam asetat 50\% dengan mencampurkan asam asetat glacial dan akuades dengan perbandingan volume 1:1 yaitu asam asetat glasial $25 \mathrm{ml}$ dengan aquades steril $25 \mathrm{ml}$ yang dituangkan dalam gelas ukur sesuai kebutuhan, kemudian menuangkan larutan tersebut kedalam falcon untuk diberi label.

Perendaman dengan kolkisin dan pengawetan jaringan

Langkah pertama merendam ikan perlakuan A1 (7 ekor), A3 (4 ekor), B1 (5 ekor), dan B2 (11 ekor) masing-masing kedalam larutan kolkisin 0,007\% w/v selama 8-10 jam yaitu mulai pukul 02.03 WIB - 12.00 WIB. Selama perendaman, ikan dibiarkan berenang dalam wadah dengan aerasi halus yang dibuat dengan memasang jarum syringe diujung selang aerasi. Memotong kecil-kecil sirip ikan uji dari masing-masing perlakuan, kemudian potongan sirip tersebut dimasukkan dalam tabung ependorf untuk direndam larutan hipotonik ( $\mathrm{KCl} 0,075 \mathrm{M})$ selama 60 menit pada suhu ruang. Mengganti larutan hipotonik dengan yang baru setiap 30 menit selama waktu perendaman dengan volume 20 kali volume jaringan. Mengganti larutan hipotonik dengan larutan carnoy, kemudian sirip difiksasi dengan larutan carnoy selama 60 menit. Larutan carnoy diganti dengan yang baru setiap 30 menit.

\section{Pembuatan Preparat dan Tahap Pewarnaan}

Mengambil sirip yang telah difiksasi menggunakan pinset dengan menyentuhkan sirip tersebut pada kertas tissue untuk menghilangkan larutan fiksatif. Meletakkan jaringan sirip tersebut di atas gelas obyek cekung atau gelas arloji kemudian ditambahkan 3-4 tetes asam asetat $50 \%$, setelah itu jaringan digerak-gerakkan dengan menggunakan pisau bedah secara hati-hati hingga terbentuk suspense sel (larutan menjadi keruh). Merendam gelas obyek yang akan digunakan sebagai preparat didalam alkohol $70 \%$ minimal selama 2 jam sebelum diletakkan di atas hot plate. Mengambil suspensi sel yang terbentuk dengan menggunakan pipet tetes lalu diteteskan diatas gelas obyek yang sudah ditempatkan diatas hot plate dengan suhu $50{ }^{\circ} \mathrm{C}$, dan dihisap kembali dengan cepat setelah terbentuk lingkaran (ring) dengan diameter 1-1,5 cm. Menunggu ring tersebut sampai kering setelah itu diangkat dan siap untuk diwarnai dengan larutan giemsa 20\%. Masing-masing gelas obyek atau preparat ditetesi 3 lingkaran atau ring.

Tahap terakhir adalah pewarnaan larutan giemsa $20 \%$ yaitu mewarnai preparat yang telah berisi lingkaran (ring) dengan larutan giemsa 20\% dengan cara memberikan larutan sebanyak 35 tetes lalu disebarkan merata hingga menutupi ring dengan menggunakan pipet tetes plastik. Pewarnaan dilakukan selama 20-30 menit pada suhu kamar. Selesai waktu pewarnaan, selanjutnya membilas preparat dengan menggunakan akuades lalu dibiarkan kering udara. Preparat yang sudah kering ditutup dengan cover glass agar ring tidak rusak terkena debu atau kotoran yang mampu merusak daripada ring tersebut. Preparat yang sudah ditutup cover glass diamati dibawah mikroskop binokuler dengan pembesaran 1000 kali untuk menghitung jumlah kromosom.

\section{Parameter yang diamati}

Keberhasilan Triploidisasi (\%)

Nurasni (2012) tingkat keberhasilan triploid daoat dihitung seperti dibawah ini.

IP $=\frac{\text { jumlah } \text { ikan triploid }}{\text { jumlah } \text { ikan sample }} \times 100 \%$

Keterangan :

IP : tingkat keberhasilan ikan triploid (\%) 
Jurnal Perikanan Pantura (JPP) Volume 1, Nomor 1, Maret 2018

Hatching Rate

Hatching rate dihitung dengan menggunakan rumus effendie, (2002) di bawah ini.

$\mathrm{HR}=\frac{\text { jumlah telur menetas }}{\text { jumlah total telur }} \times 100 \%$

Keterangan :

HR : Daya tetas telur (\%)

HASIL DAN PEMBAHASAN

Keberhasilan Triploid

Tabel 1. Data pengamatan dan analisis keberhasilan triploid

\begin{tabular}{llllll}
\hline Perlakuan & Ulangan & $\begin{array}{l}\text { Jumlah } \\
\text { Kromosom } \\
\text { Diploid }\end{array}$ & $\begin{array}{l}\text { Jumlah } \\
\text { Kromosom } \\
\text { Triploid }\end{array}$ & $\begin{array}{l}\text { Jumlah } \\
\text { Ikan } \\
\text { Diploid }\end{array}$ & $\begin{array}{l}\text { Jumlah } \\
\text { Ikan } \\
\text { Triploid }\end{array}$ \\
\hline \multirow{2}{*}{ A (lama kejut suhu 1,5 menit) } & 1 & $83-100$ & $140-150$ & 3 & 4 \\
& 3 & 93 & $124-149$ & 2 & 2 \\
B (lama kejut suhu 2 menit) & 1 & $97-100$ & $128-150$ & 2 & 3 \\
& 2 & $91-100$ & $127-143$ & 8 & 3 \\
\hline
\end{tabular}

Hasil dari pengamatan preparat dibawah mikroskop menunjukkanperlakuan A jumlah kromosom ikan triploid $(3 \mathrm{~N})$ sebanyak 124 - 150 buah kromosom dan jumlah kromosom ikan diploid (2N) sebanyak 83 - 100 buah kromosom. Perlakuan B jumlah kromosom Ikan triploid $(3 \mathrm{~N})$ sebanyak 127 - 150 dan jumlah kromosom ikan diploid (2N) sebanyak 91 - 100 buah kromosom. Hal ini sesuai dengan pernyataan Carman dan Maulana (2016) bahwa, jumlah kromosom ikan mas (Cyprinus carpio L) haploid sebanyak 50 buah kromosom, diploid sebanyak 100 set kromosom, dan triploid sebanyak 150 buah kromosom. Berikut perbedaan jumlah kromosom ikan triploid dan diploid (normal) dapat dilihat pada Gambar 1 yang didapat dari foto mikroskop.

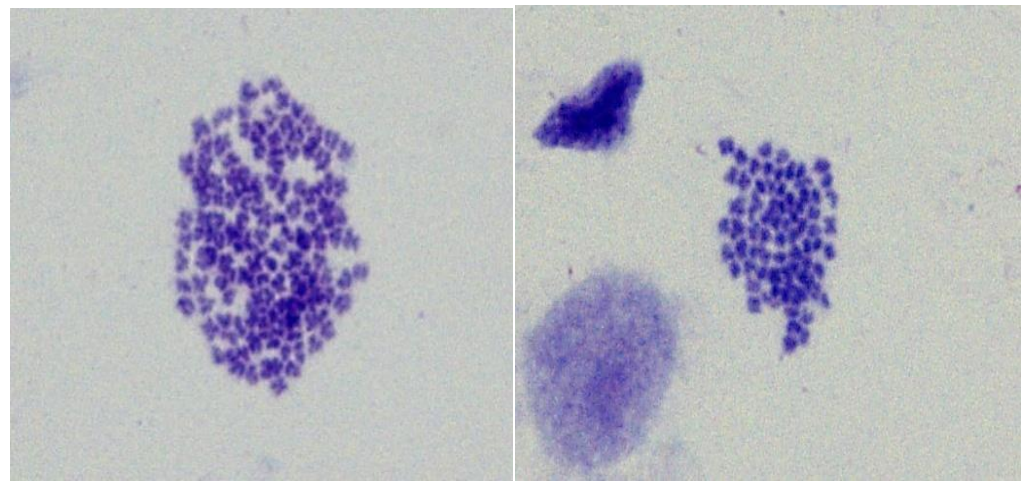

\section{Gambar 1. Sampel kromosom triploid (a) dan diploid (b) ikan mas punten pada sirip} dengan pembesaran 1000 kali.

Bervariasinya jumlah kromosom pada penelitian ini akibat dari kurang menyebar dan tertutupnya sebaran kromosom oleh pewarnaan. Bentuk dan sebaran kromosom sangat dipengaruhi oleh lamanya waktu perendaman larutan kolkisin 0,007\% dan umur larva atau benih yang akan diuji kromosom. Tidak semua larva menghasilkan sebaran kromosom tepat metafase karena adanya respon individu terhadap pengaruh kolkisin atau mungkin kolkisin tidak berfungsi dengan baik karena larva ikan yang stress saat perendaman atau umur larva yang terlalu matang yang mengakibatkan pembelahan sel akan mengalami penurunan jika dibanding umur larva yang masih tergolong juvenil sebagaimana keaktifan pembelahan sel lebih baik dan tinggi. Umur larva 
yang lebih tua akan lebih sulit pemecahan dan penyebaran kromosom dibanding umur larva yang lebih muda untuk di analisis jumlahnya kromosomnya. Menurut Said dkk. (2003) bentuk dan sebaran kromosom terbaik diperoleh dari larva umur 10 hari, dosis kolkisin 0,070\% dengan waktu inkubasi selama 9 jam dan perlakuan hipotonik selama 90 menit. Said (2001) menyatakan bahwa, untuk mendapatkan preparat yang terbaik terdapat spesifikasi dalam hal umur larva, dosis kolkisin, lama waktu inkubasi baik dalam larutan kolkisin maupun dalam larutan hipotonik. Berikut persentase ikan triploid dapat dilihat pada gambar 2.

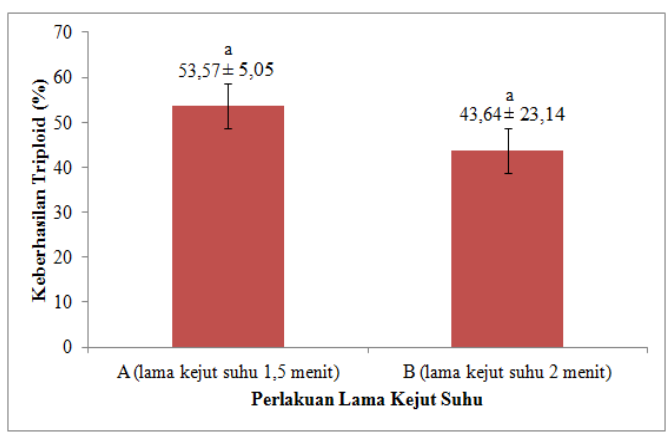

Gambar 2. Histogram keberhasilan triploid (\%)

Berdasarkan Gambar 2 menunjukkan lama kejut suhu panas 1,5 menit menghasilkan

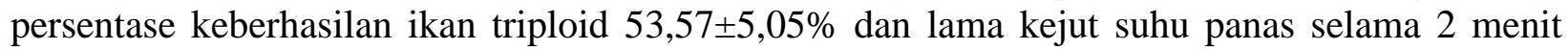
menghasilkan persentase keberhasilan ikan triploid 43,64 $23,14 \%$. Hasil uji T-test menunjukan bahwa kejut suhu $40^{\circ} \mathrm{C}$ dengan lama 1,5 menit (perlakuan A) dan 2 menit (perlakuan B) tidak memberikan pengaruh yang signifikan terhadap keberhasilan triploid (\%) ikan mas (Cyprinus carpio $\mathrm{L})$ ras punten $(\mathrm{P}>0,05)$, yang dapat dilihat pada Tabel 1.

Tabel 1. Uji T-test dan korelasi antara perlakuan lama kejut suhu dan keberhasilan triploid (\%) ikan mas (Cyprinus carpio L) ras Punten

\begin{tabular}{lllll}
\hline & $\begin{array}{l}\text { Perbandingan perlakuan } \\
\text { dan parameter }\end{array}$ & $\begin{array}{l}\text { N (jumlah } \\
\text { data) }\end{array}$ & $\begin{array}{l}\text { Korelasi } \\
\text { (hubungan) }\end{array}$ & Signifikan \\
\hline Pair 1 & $\begin{array}{l}\text { Lama kejut suhu (menit) dan } \\
\text { keberhasilan triploid (\%) }\end{array}$ & 4 & $-0,387$ & 0,613 \\
\hline
\end{tabular}

Ket: non signifikan (ns) atau tidak berbeda nyata

Mukti dkk (2001) menyatakan bahwa, kejut suhu $40^{\circ} \mathrm{C}$ dengan lama waktu 1,5 menit yang dilakukan 3 menit setelah fertilisasi menghasilkan ploidi sebesar 61,7\%, dimana hasil tersebut lebih besar dibanding hasil keberhasilan triploid pada penelitian ini. Penyebab dari perbedaan tersebut diduga karena pemberian waktu awal kejut suhu 3 menit setelah fertilisasi merupakan waktu yang tepat dimana sel telur mengeluarkan polar body IIkemudian tertahan akibat kejut suhu tersebut, sehingga pada penelitian ini waktu awal pemberian kejut suhu 2 menit setelah fertilisasi merupakan waktu yang kurang tepat dimana sel telur belum mengeluarkan polar body II atau belum terjadi tingkat meiosis II. Nurasni (2012) menyatakan bahwa, kisaran proses meiosis II yang terjadi sekitar 3-7 menit setelah pembuahan, sehingga terjadi proses pelepasan polar body II. Komen dalam Mukti dkk (2001) juga mengatakan bahwa, peloncatan polar body II terjadi pada 5 menit setelah fertilisasi.

Kusuma (2017) menyatakan bahwa, suhu kejut panasmerupakan salah satu faktor utama dalam mengubah kromosom dari diploid (2n) menjadi triploid (3n) pada beberapa saat setelah fertilisasi. Diketahui lama waktu pemberian kejutan suhu juga dapat mempengaruhi tingkat keberhasilan dari triploidisasi pada ikan (Hartono dan Purbosari, 2010). Sedangkan menurut 
Edriani dkk. (2009) menyatakan bahwa, ada kemungkinan tidak menetasnya atau tidak berhasilnya suatu proses triploidisasi disebabkan oleh lamanya waktu kejutan yang diberikan pada telur dan kesesuaian metode triploidisasi terhadap telur ikan.

Keberhasilan triploid sendiri merupakan banyaknya jumlah ikan yang mempunyai kromosom $3 \mathrm{~N}$ atau setengah lebih banyak dari ikan normal (diploid). Proses triploidisasi pada ikan perinsipnya adalah mencegah atau menahan terjadinya peloncatan polar body II dari telur atau pembelahan meiosis II (Mukti dkk2001). Menurut Shapperd dan Bromage (1996) bahwa, ikan triploid merupakan salah satu manipulasi kromosom yang digunakan untuk memperbaiki kualitas genetik ikan sehingga menghasilkan benih ikan yang mempunyai keunggulan antara lain pertumbuhan cepat, toleransi terhadap lingkungan yang ekstrim dan tahan terhadap serangan penyakit. Hal ini disebabkan ikan triploid memiliki sifat mandul karena tidak dapat melangsungkan proses perpasangan kromosom, sehingga energi yang digunakan untuk reproduksi pada ikan diploid digunakan untuk pertumbuhan somatik atau tubuh pada ikan triploid, sehingga pertumbuhannya lebih cepat (Pristiariyoto dkk,2013).

\section{Hatching Rate}

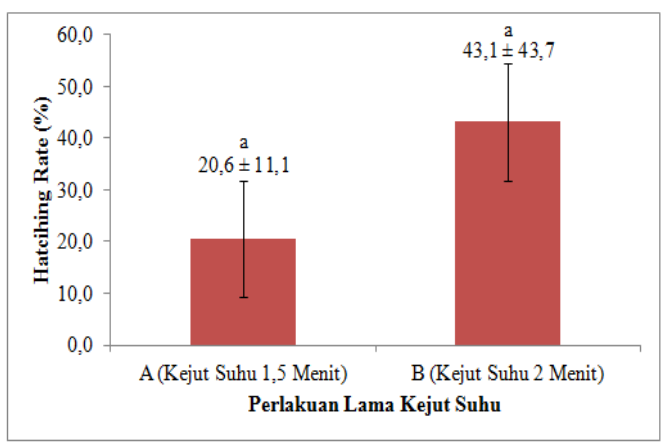

Gambar 3. Histogram hatching rate $(\%)$

Berdasarkan Gambar 3, lama kejut suhu panas selama 1,5 menit menghasilkan persentase hatching rate 20,6 $\pm 11,11 \%$ dan lama kejut suhu panas selama 2 menit menghasilkan persentase hatching rate $43,1 \pm 43,74 \%$. Hasil uji $T$-test menunjukan bahwa kejut suhu $40^{\circ} \mathrm{C}, 2$ menit setelah fertilisasi dengan lama 1,5 menit (perlakuan A) dan 2 menit (perlakuan B) tidak memberikan pengaruh yang signifikan terhadap daya tetas telur ikan mas (Cyprinus carpio L) ras punten $(\mathrm{P}>0,05)$ (Tabel 2).

Tabel 2. Uji T-test dan korelasi antara perlakuan lama kejut suhu dan hatching rate (\%) ikan mas (Cyprinus carpio L) ras Punten

\begin{tabular}{lllll}
\hline \multicolumn{2}{c}{$\begin{array}{l}\text { Perbandingan perlakuan } \\
\text { danparameter }\end{array}$} & $\begin{array}{l}\text { N (jumlah } \\
\text { data) }\end{array}$ & $\begin{array}{l}\text { Korelasi } \\
\text { (hubungan) }\end{array}$ & Signifikan \\
\hline Pair 1 & $\begin{array}{l}\text { Lama kejut suhu (menit) } \\
\text { dan hatching rate (\%) }\end{array}$ & 6 & 0,397 & 0,435 \\
\hline
\end{tabular}

Ket. non signifikan (ns) tidak berpengaruh nyata (Sig>95\%)

Mukti dkk (2001) kejut suhu panas $40^{\circ} \mathrm{C}$ selama 1,5 menit yang dilakukan 3 menit setelah fertilisasi pada ikan mas punten menghasilkan daya tetas $22,63 \pm 8,36 \%$, dimana hasil ini lebih besar jika dibandingkan dengan hasil penelitian ini. Akibat dari perbedaan tersebut diduga karena ketepatan waktu awal kejut suhu pada penelitian ini yaitu 2 menit setelah fertilisasi perkembangan zigot pada telur belum mampu menahan kejut suhu panas sehingga mengakibatkan kerusakan pada benang-benang spindel yang terbentuk saat proses pembelahan sel dalam telur atau rusaknya mikrotubulus yang membentuk spindel selama pembelahan sel 
pada telur, jadi dapat disimpulkan kematangan atau perkembangan zigot pada waktu pemberian kejut suhu 2 menit setelah fertilisasi kurang tahan terhadap kejut suhu panas $40^{\circ} \mathrm{C}$. Bidwell dkk (1985) menyatakan bahwa, kejutan panas menyebabkan depolimerisasi pada polimer tubulin dalam mikrotubulus yang essensiel dalam pembentukan spindel. Mustami (2013) juga menyatakan bahwa, ada kecenderungan semakin tinggi tingkat kematangan gonad saat pembelahan sel yang terjadi pada zigot, daya tahan zigot pada kejut suhu panas semakin baik atau embrio tua lebih toleran terhadap suhu ekstrim dibanding embrio muda.

Mustami (2013) menyatakan bahwa, pemberian kejut suhu panas $40^{\circ} \mathrm{C}$ selama 2 menit dengan waktu awal 3 menit setelah fertilisasi menghasilkan rata-rata daya tetas $28,967 \%$, dimana hasil tersebut lebih kecil jika dibandingkan dengan perlakuan B pada penelitian ini, diduga karena perkembangan telur pada penelitian ini lebih seragam kematangannya, sehingga rendahnya hatching rate pada penelitian di atas dapat diduga akibat perkembangan telur masih dalam fase gastrula dimana sering terjadi kematian pada fase ini. Mukti dkk (2001) menyatakan bahwa, fase gastrula merupakan fase rawan pada perkembangan telur sehingga kematian tertinggi akan terjadi pada fase ini.

Faktor lain yang dapat mempengaruhi hatching rate yaitu pemberian kejut suhu panas yang akan mengganggu proses dari embryogenesis ikan mas (Cyprinus carpio L) ras Punten sesuai dengan pernyataan Hartono dkk. (2016) bahwa, semakin tinggi suhu kejut dan semakin lama waktu kejut yang diberikan pada proses triploidisasi maka jumlah total telur yang akan menetas akan semakin menurun. Menurut Kusuma (2017) bahwa, dikarenakan suhu panas mampu mendenaturasi protein pada telur, sehingga ketika telur diberi kejutan panas yang melampaui toleransi telur tersebut maka protein yang terkandung didalam telur tersebut berpotensi akan terdenaturasi dan akan mengganggu bahkan mampu menggagalkan proses dari embrio genesis ikan tersebut.

\section{KESIMPULAN DAN SARAN \\ Kesimpulan}

1. Hasil analisis jumlah kromosom pada proses triploidisasi ikan mas punten dengan lama kejut suhu panas 1,5 menit menghasilkan keberhasilan ikan triploid 53,57+5,05\% dan lama kejut suhu panas 2 menit menghasilkan keberhasilan ikan triploid 43,64 $\pm 23,14 \%$.

2. Triploidisasi ikan mas punten dengan lama kejut suhu panas 1,5 menit menghasilkan persentase hatching rate 20,6 $\pm 11,11 \%$ dan lama kejut suhu panas 2 menit menghasilkan $43,1 \pm 43,74 \%$.

\section{Saran}

1. Perlu dikembangkan penelitian lanjutan guna mencari lama perendaman kejut suhu, waktu kejut suhu dan derajat kejut suhu untuk meningkatkan jumlah ikan triploid (kromosom 3N) yang terbaik pada ikan Mas (Cyprinus carpio Linn) ras Punten.

2. Metode analisis kromosom pada jaringan padat juga perlu dikembangkan khususnya pada umur ikan uji dan lama perendaman larutan kolkisin yang optimal untuk mendapatkan bentuk dan sebaran kromosom yang terbaik sehingga dapat mudah dihitung.

\section{DAFTAR PUSTAKA}

Bai Z, Liu F, Li J, Yue GH. 2011. Identification of Triploid Individuals and Clonal Line in Carassius auratus Complex using Microsatellite. Int. J. Biol. Sci. 7: 279-285.

Bidwell, C. A., Chrisman, C. L. dan Libey, G. S. 1985. Polyploidy Induced by Heat Shock in Channel Catfish. Aquacultur, 57: 362.

Carrman, O. dan Maulana, F. 2016. Analisis Laboratorium Reproduksi dan Genetika Organisme Akuatik. Fakultas Perikanan dan Ilmu Kelautan. Institut Pertanian Bogor. Bogor. 
Edriani, G., D. Silmina dan W. Afrilasari. 2009. Pengaruh Lama Kejutan Suhu Terhadap Keberhasilan Teknik Triploidisasi pada Ikan Komet (Carasius auratus auratus). Skripsi. Istitut Pertanian Bogor. Bogor.

Firmantin, I. T., Sudaryono, A., Nugroho, R. A. 2015. Pengaruh Kombinasi Omega-3 dan Klorofil Dalam Pakan Terhadap Fekunditas, Derajat Penetasan dan Kelulusan Hidupan Benih Ikan Mas (Cyprinus carpio). Fakultas Perikanan dan Ilmu Kelautan. Universitas Diponegoro. Semarang.

Hariani, D. 2008. Daya Tetas Ikan Mas (Cyprinus carpio) Hasil Triploidi Menggunakan Larutan Kolkhisin. WAHANA. Vol: 51, No: 2. Hal:72-80

Kumbarani, I, N. 2015. Teknik Ginogenesis Ikan Mas Punten (Cyprinus carpio L) di Instalasi Budidaya Air Tawar Punten Kota Batu, Jawa Timur. Fakultas Perikanan dan Kelautan. Universitas Airlangga. Surabaya.

Kusuma, S. G. 2017. Pengaruh Kejutan Suhu Panas Terhadap Usaha Triploidisasi Ikan Rainbow Boesemani (Melanotaenia boesemani). Fakultas Perikanan dan Ilmu Kelautan. Universitas Brawijaya. Malang.

Mukti, A. T. 2017.Metode Penentuan Ploidi pada Ikan Nila (Oreochromis niloticus) Menggunakan Kombinasi Sebaran Kromosom dan Nukleoli Secara Bersamaan. Fakultas Perikanan dan Kelautan. Universitas Airlangga. Surabaya

Mukti, A.T., Rustidja, A.B. Sumitro, dan M.S. Djati. 2001. Polyploidisasi ikan Mas (Cyprinus carpio L.). BIOSAIN 1(1): 111-123.

Mustami, M, K. 2013. Tingkat Penetasan Relatif Telur Ikan Mas (Cyprinus carpio Linn) ras Punten Yang Diberikan Kejutan Suhu Panas Untuk Memproduksi Ikan Poliploid. Fakultas Sains Dan Teknologi. UIN Alauddin Makassar. Makassar.

Nurasni, A. 2012. Pengaruh Suhu dan Lama Kejutan Panas Tehadap Triploidisasi Ikan Lele Sangkuriang (Clarias gariepinus). Universitas Padjadjaran. Sumedang.

Piferrer F, A Beaumont, JC Falgulere, L Colombo. 2007. Performance improvements by polyploidization in aquaculture. Institut de Ciencies del Mar, Barcelona, Spanyol.

Pristiariyoto, P., Isnawati dan N. Kuswanti. 2013. Pengaruh konsentrasi dan lama perendaman telur dalam larutan kolkhisin terhadap laju pertumbuhan ikan patin (Pangasius pangasius). Lentera Bio. 2(3): 229-232.

Purnawan, S. 2016. Pengaruh Umur Zigot Pada Saat Kejutan Panas Terhadap Keberhasilan Ginogenesis Ikan Seurukan (Osteochilus vittatus). Universitas Syiah Kuala Darussalam. Banda Aceh.

Risnandar D. 2010. Pengaruh umur zigot pada saat kejutan panas terhadap tingkat keberhasilan triploidisasi, serta kelangsungan hidup embrio dan larva lkan jambal siam (Pangasius hypophthalmus). [12 Februari 2011].

Said, S. Djamhuriyah., O. Charman., Hidayat dan Abinawanto. 2003. Studi Kromosom Ikan Pelangi (Melanotaenia lacustris). Jurnal Iktiologi Indonesia. 3(2): 79-85.

Santoso, B. 2008. Petunjuk Praktis Budidaya: Ikan Mas. Kanisius, Yogyakarta. $77 p$.

Setyono, B. 2009. Pengaruh Perbedaan Konsentrasi Bahan pada Pengencer Sperma Ikan "Skim Kuning Telur" Terhadap Laju Fertilisasi, Laju Penetasan, dan Sintasan Ikan Mas (Cyprinus carpio Linn). Fakultas Pertanian dan Peternakan. Universitas Muhammadiyah Malang. Malang

Susanto. 2004. Budidaya Mas. Kanisius. Jakarta.

Widiyanti, P. Marlina. 2008. Tetraploidisasi ikan lele Afrika (Clarias gariepinus, Burchell 1822). Skripsi. Institut Pertanian Bogor, Bogor. 55 hlm. 